\title{
Identifying Refugia and Barriers to the Spread of A. graminifolia and D. crumenatum in Puerto Rico
}

Evan Foster ${ }^{1}$, James D. Ackerman ${ }^{2}$ and Wilfredo Falcón L. ${ }^{3}$

1 Department of Environmental Sciences, Colorado College

2 Department of Biology, University of Puerto Rico

${ }^{3}$ Research Department, Eco-Caribe LLC

Corresponding author: EV, e_foster@coloradocollege.edu

\section{Summary}

Establishment of new populations is contingent on overcoming abiotic and biotic barriers. While this applies to all species, these hurdles are at the forefront of invasion biology where prediction, prevention, eradication, and control strategies depend on an understanding and exploitation of barriers to establishment and spread. Arundina graminifolia and Dendrobium crumenatum are two invasive orchids spreading throughout Puerto Rico. Current records on their distributions across the island are sparse, and their interactions with the surrounding ecosystem are unknown. Through a direct population survey of all known localities, we identified a new, acquired enemy of both orchids: the orchid-specialist weevil, Stethobaris polita. In this study, we used niche modelling to identify suitable habitats for each orchid on the island and map their current distributions and interactions with $S$. polita, along with their distributions in the most extreme climate scenario in 2050, in order to contextualize projected patterns of establishment on the island. Our findings show that $D$. crumenatum flourishes in urban environments which also provide refugia from $S$. polita. In contrast, there is currently no refugia for A. graminifolia from $S$. polita attack, as it is more sensitive to the same climatic variables as $S$. polita. Furthermore, projections into the most extreme climate scenario suggests Puerto Rico will be unsuitable for A. graminifolia and S. polita's survival, and become less suitable for D. crumenatum, by 2050.

\section{Introduction}

Over the past century, our natural world has dealt with new, largely human-induced problems at an unprecedented scale. Terrestrial ecosystems are under siege from rapid deforestation and expanding urbanization, to a climate system shifting at a rapid rate, all of which are associated with greater frequencies of 
biological invasions (ref.). These changes are prevalent worldwide, and exacerbated on islands (D'antonio and

Dudley, 1995; Denslow et al. 2009; Pulwarty et al. 2010) where some impacts are obvious and dramatic,

whereas others are subtle, small and unexpected (e.g., Vitousek and Walker, 1989; O’Dowd et al., 2003; Sin et

al., 2008; Recart et al., 2013). Certainly habitat heterogeneity and biotic and abiotic clines affect invasional

success and geographic spread (Lockwood et al. 2007). For example, climate change can facilitate or impede

invasive establishment and spread (Kolanowska et al. 2017; Ongaro et al, 2018). The heat island effect can

increase surrounding temperatures, locally exaggerating current warming trends (Oke, 1973; Parker, 2009;

McCarthy et al., 2010). Additionally, urban areas facilitate non-native prominence, and can provide refuge for

invasive species from biotic resistance (McKinney, 2006; Burton et al., 2005; Holway, 1995; Vila \& Pujadas,

2001), as is observed for the invasive orchid Spathoglottis plicata in Puerto Rico (Soifer and Ackerman, 2019).

In Puerto Rico, barrages of new, invasive species are being introduced (e.g., Rojas-Sandoval \&

Acevedo-Rodríguez, 2016; Falcón \& Tremblay, 2018). Often overlooked are the increasing numbers of exotic

orchids (Ackerman, 2007). Although orchids are disproportionately underrepresented among invasive species

(Daehler 1998), those that are can have both positive and negative impacts (e.g. apparent competition, Recart et

al. 2013). For this reason, it is important to identify recent invasions and factors associated with their

establishment, spread and consequences to invaded communities.

In this paper, we focus on populations of Arundina graminifolia and Dendrobium crumenatum, two invasive Asiatic orchids in Puerto Rico. Current knowledge on both species in Puerto Rico, beyond herbarium collections, is rather sparse. The first naturalized population of $A$. graminifolia was discovered a few kilometers from an orchid nursery which had a stand of them on the nursery grounds, so it is likely they arrived via the horticultural trade as has happened elsewhere (Ackerman, 1995, 2012). Since their original discovery, both populations have spread across the island, as evidenced by local herbarium records. As both invasions continue to spread across the island over the coming decades, understanding their fullest possible extent ahead of time can provide useful information for future research and/or mitigation efforts on either species. 
While modelling distributions and recording climatic responses, it is important to contextualize both invasions with their known ecological interactions and with the impending changes in the current climate system. For both orchids, there are no published records of acquired enemies (herbivores, seed predators) in Puerto Rico, but we have seen native Stethobaris polita, an orchid specialist weevil, attacking buds, flowers and fruits of both species. Such attacks on other orchids have led to severe flower damage, and their ovipositing in the fruits can compromise fruit set (Recart et al, 2013). The implications of this interaction for both species on the island remains unknown, however the introduction of additional exotic orchids might pose additional risk to native orchids through apparent competition (Recart et al, 2013). In this way, understanding the extent of these interactions with $S$. polita across the island can also be particularly useful in understanding their greater ecological impacts. Previous research suggests $S$. polita does not inhabit urban landscapes, either due to an inability to penetrate or to establish within such environments (Soifer \& Ackerman, 2019). For orchids like $D$. crumenatum that have naturalized within these areas, they can be freed from such herbivore attack. Such refugia has been observed in S. plicata, another exotic orchid in Puerto Rico (Soifer \& Ackerman, 2019). A. graminifolia is found at higher elevations than the current urban extent, however there might be additional climatic barriers providing refugia from S. polita attack.

Both species exhibit signs of high climate sensitivity, making their responses to climate change particularly important in modelling their distributions. A. graminifolia is found naturally at higher elevations, indicating a sensitivity towards higher temperatures. Previous research has established a negative relationship in A. graminifolia's habitat suitability globally under any climate change scenario, although the specific implications for this loss is unknown for Puerto Rico (Kolanowski and Konowalik, 2014).

For D. crumenatum, there is no standing research on its limiting climatic variables, much less it's response to climate change. However, a strong --and perhaps unusual-- climatic response might be expected for D. crumenatum, since it's reproductive success and population health directly relies on the weather. The gregarious flowering of $D$. crumenatum triggered by rain-induced temperature drops have been well- 
documented (Seifriz, 1923; Goh et al. 1982; Brooks and Hewitt, 1909). In order for current distribution models of D. crumenatum to remain applicable in the coming decades, they must account for scenarios with an altered climate.

In general, little to no research has been conducted on the distributions of A. graminifolia and $D$. crumenatum in Puerto Rico, or how these populations relate to their greater environment. As both populations continue to spread and establish on the island, it is important to understand how enemy acquisition, urbanization, and climate change will influence both invasive populations in the future.

\section{Objectives:}

Our research intends to establish an understanding of the variables influencing A. graminifolia and $D$. crumenatum distributions in Puerto Rico in the present, allowing us to predict what their futures hold on the island. In order to do so, our project is split into three objectives, each probing a variable that might have a demonstrable effect on both/either orchid species. Our first objective is to determine whether enemy release or enemy acquisition is occurring for $A$. graminifolia and $D$. crumenatum, and to what extent it may affect reproductive success. Our second objective is to assess whether anthropogenic disturbances provide refugia for both orchid species from herbivore attack. Our third objective is to determine the responses of A. graminifolia and $D$. crumenatum to future climate conditions; primarily along the basis of their distributions and relationships.

\section{Hypotheses:}

\section{Enemy Acquisition}

The orchid-specialist weevil, Stethobaris polita, has been observed feeding on the reproductive structures of both orchid species (field observation). However, there are other herbivorous invertebrates that attack orchids in Puerto Rico, such as other weevils, aphids, and snails (summarized by Martorell and Gaud, 
1974). It can be expected that some of these other herbivores will also attack $A$. graminifolia and $D$.

crumenatum, although the prevalence of these interactions is still unknown. Regardless, if $S$. polita frequently attacks $A$. graminifolia and D. crumenatum, then we expect that other herbivores will also attack them. In quantifiable terms, we expect areas with higher abundances of enemies to subsequently have reduced reproductive success, indicated by lower fruit production and/or pollinarium removals.

\section{Presence of Refugia from Enemies}

Populations of D. crumenatum can be found in the urban landscapes of San Juan. Most likely, these orchids were originally planted artificially by humans, where they then had reproductive success and naturally established within urban forests and other urban areas (personal observation). At the same time, a common culprit of orchid herbivory, the orchid-specialist weevil S. polita, is unable to travel into or establish within urban areas, remaining largely absent from those locations (Soifer and Ackerman, 2019). If there is this disparity between herbivore and plant, then there will be a forest-urban gradient for the $D$. crumenatum, similar to what is seen in the S. plicata. At the same time, however, since A. graminifolia has naturalized only at elevations above $500 \mathrm{~m}$, far above the extent of most current urban areas, the reliance of Arundina on the bioclimatic variables associated with higher altitudes will prevent the species from establishing within lowland urban centers. Furthermore, the presence of $A$. graminifolia within those areas are completely facilitated by/ reliant upon human dispersion and care. However, other barriers to enemy establishment that might be associated with the current extent of $A$. graminifolia (e.g. bioclimates, soil types, elevation) could create refugia for A. graminifolia from its enemies.

\section{Response to Climate Change}

Previous models of $A$. graminifolia in Central and South America show a noticeable decrease in suitable habitats under every climatic warming scenario provided by the IPCC (Kolonawska and Konowalik, 2014). 
This makes sense, as A. graminifolia are only found at higher elevations in Puerto Rico, indicating a possible reliance/preference on the cooler bioclimatic variables associated with those elevations. This fragility to warmer temperatures might force an altitudinal range shift to higher elevations (Lenoir et al. 2008; Walther et al. 2002).

Clearly, if invasive populations of $A$. graminifolia are vulnerable to future climate change, then we would expect either a future die-off, or a restricted growth in distribution, of the invasive $A$. graminifolia populations in Puerto Rico within the coming decades, possibly minimizing their overall effects on the native species in Puerto Rico.

On the other hand, D. crumenatum relies almost exclusively on a surrounding temperature drop to signal a synchronous flowering (Seifriz, 1923; Goh et al. 1982; Brooks and Hewitt, 1909). Considering how the orchids rely on temperature change, rather than a specific temperature, the vulnerability of such orchids to climate change will largely be determined by the temperature variability at lower altitudes as a result of climate change. Dendrobium crumenatum could hypothetically see greater reproductive success and more frequent flowering, or the exact opposite. Regardless, the distribution of D. crumenatum in Puerto Rico will be affected by climate change in a major way.

\section{Materials and Methods}

Study Site:

The study was conducted during June and July 2019 across the Carribean island of Puerto Rico. Populations were monitored mainly along roadsides and in front yards, although a few populations were found along trails and streams. The locations of individual populations were identified from herbarium collections and personal communications. Populations were also identified through incidental discovery, either during travels between known populations, or through intentional scouting in previously unexplored municipalities.

We collected data from the following municipalities: Adjuntas, Aibonito, Barranquitas, Caguas, Carolina, Cayey, Cidra, Jayuya, Lares, Luquillo, Naranjito, Orocovis, Patillas, Río Grande, San Juan, San Sebastian, Trujillo Alto, and Utuado. 
Field Work:

We collected GPS coordinates and plant data for populations along roadsides, private properties, and trails. Populations were only considered if there was evidence of naturalization and/or recruitment. Populations could meet this criteria in a number of ways: the presence of reproductive structures (i.e. fruiting bodies) on at least one plant, the presence of recruits in the population, or sufficient circumstantial evidence that the population was not cultivated. Even if a population was originally cultivated, it was still included if successful recruitment was evident, acknowledging the role of the horticultural trade as a vector in exotic orchid dispersal. At each designated study site, we identified a "target plant," which we categorized as an orchid with reproductive structures closest to the center of the population. We collected the waypoints for the target plant with a GPS system, and measured the distance of the target plant to its five nearest neighbors (within a $30 \mathrm{~m}$ radius). We averaged these distances to calculate a proxy for population density. For plants without reproducing neighbors within a $30 \mathrm{~m}$ radius, their density measure is greater than or equal to $30 \mathrm{~m}$ (i.e. the average of nearest neighbors is at least $30 \mathrm{~m}$ ).

At each target plant and their five nearest neighbors, we gathered data on its anatomical and biological characteristics, particularly those that are important for establishment and success in the next generation. More specifically, for populations of D. crumenatum we measured the number of active shoots, the length and width of the largest pseudobulb, plant height from ground, total number of fruits, and the number of damaged fruits. Due to the erratic flowering of $D$. crumenatum, flower data could not be taken at most sites. When plants were found in flower, we counted total flower number and identified reproductive success by identifying pollinaria removals and pollinations. Due to the large number of flowers associated with the synchronous flowering spectacle of $D$. crumenatum, we sampled all available flowers or a random sample to a maximum of 30 flowers for pollinarium removals and pollinations. 
For A. graminifolia, we measured the petal width, throat width, lip length, and height of each plant's

flowers. We measured the height of fruiting bodies. We also recorded the number of scars for each active shoot.

Similar to D. crumenatum, we identified pollinaria removal and deposits. We recorded the damage to flower petals, throat, lip, and sepils, along with the damage to fruits.

At every population, we recorded the number of $S$. polita present, along with the presence of other possible enemies. We categorized weevil presence at a waypoint from either weevil sightings or evidence of weevil damage and damaged reproductive structures (buds, flowers, fruits). We quantified the degree of damage to plants and populations by designating a damage score for each flower and fruit, on a 1-10 scale. By scoring each structure individually, we could effectively average the total damage to each plant and to entire populations.

Distribution Modelling and Mapping:

Land use will be quantified into three categories of disturbance, similar to previous studies: urban forests (0-33\% undisturbed habitat), rural forests (34-66\% undisturbed habitat), and continuous forest (67-100\% undisturbed habitat) (Soifer and Ackerman, 2019). Specific land cover type and habitat composition of our study sites was determined using QGIS and the land cover map from the Puerto Rico GAP Analysis Project (PRGAP) (2006).

Maxent:

We modelled the distributions of $A$. graminifolia and D. crumenatum using Maxent v 3.4.1 (Phillips et al. 2019), similar to previous studies on invasive species distribution in both the present and future (Soifer and Ackerman, 2019; Kolanowska and Konowalik, 2014). We ran the presence-only data for both species against ten environmental layers, including eight climatic layers from Worldclim Version 2-Global Climate Data (Fick and Hijmans, 2017). The climatic layers chosen were based off of similar studies on the same study species, or 
within the same study area, which we hope to compare our data the closest to: annual mean temperature (Bio

01), temperature seasonality (Bio 04), maximum temperature of warmest month (Bio 05), minimum

temperature of warmest month (Bio 06), mean temperature of driest quarter (Bio 09), precipitation seasonality

(Bio 15), precipitation of wettest quarter (Bio 16), and precipitation of driest quarter (Bio 17) (Soifer and

Ackerman, 2019; Kolanowska, 2014; Recart et al., 2013). This set of environmental layers will be narrowed

down before publication, as we have not run GLM's between each climatic layer to eliminate those that are

highly correlated. We also included land cover and elevation (PRGAP 2006). Bioclim variables and elevation

were set at a spatial resolution of 30 arc-seconds $(\sim 1 \mathrm{~km})$, with land cover at $15 \mathrm{~m}^{2}$ (Gould et al., 2008). We

prepared the layers for Maxent on ArcGIS to match the extent, cell size, and coordinate system of the PRGAP

land cover map. We also used ArcGIS to match our GPS coordinates with the coordinate system of the

environmental layers.

Samples included a total of 30 populations of D. crumenatum, 28 populations of $A$. graminifolia, and

140 populations of $S$. polita. For any cell with more than one population, only one was used to contribute to the

model. Since presence points for S. polita would be limited to the presence points of our two orchids, their

modelled distribution might create an incomplete picture of their overall distribution. To counteract this

discrepancy, we combined our S. polita presence points with those recorded with a third orchid, Spathoglottis

plicata (see: Soifer and Ackerman, 2019). For this reason, the number of populations of $S$. polita is noticeably

higher than those of either orchid.

We ran logistic models for A. graminifolia, D. crumenatum, and S. polita under the default settings,

while running a 10-fold cross-validation to estimate error around the mean model, which has been identified as a reliable method for projecting onto novel climate scenarios (Elith et al 2010). We applied the threshold rule of

Equal Training Sensitivity and Specificity, similar to previous studies.

We used these same climatic layers as we project orchid population response under various climatic scenarios (RCPP 2.6 and 8.5 ), supplied by Ramirez and Jarvis (2008), and utilized by similar studies (Coops 
and Waring, 2011; Kolanowska and Konowalik, 2014; Barredo et al. 2015; Kolanowska et al. 2017). While the

accuracy of such projections remain unknown, and their overall reliability remains highly contested (Araújo and Peterson, 2012), we are following the guidelines set by previous studies to ensure more accurate modelling (Elith et al 2010).

Statistical Analysis:

Along with modelling species distributions, Maxent also provides multiple statistical tests on model significance and performance. We used the area under the receiver operating characteristic (ROC) curve (AUC) to assess model quality and discern model output from a random prediction. We conducted jackknife tests for each important variable, allowing us to determine the relative importance that variable has in determining the model.

Following the conclusion of this REU, we will run chi squared tests and generalized linear models for abundance of herbivores on the degree of herbivory, reproductive success (fruit set and production), and plant density of $A$. graminifolia and $D$. crumenatum. We will also run abundance of herbivores against the flowering of Arundina, along with the relationship between Arundina's flower size and fruit set. We These will all be conducted with climatic variables held constant. Together, these tests should illustrate which factors are most important in explaining various outcomes of orchid distribution and health.

\section{Results}

Enemy Acquisition:

Field observations show that both $A$. graminifolia and $D$. crumenatum have acquired a new enemy in the form of S. polita. Enemy attack is more common for A. graminifolia than it is for D. crumenatum. Of the 30 
populations of $D$. crumenatum surveyed, only 6 contained evidence of $S$. polita damage. In comparison, 20 of

the 28 A. graminifolia populations surveyed had evidence of $S$. polita damage. Some $A$. graminifolia flowers

could be seen with damage to their sepils, lip, and/or petals, with $S$. polita present (Fig. 6). S. polita was also

seen boring into A. graminifolia fruits. Identical damage markings were found on other A. graminifolia flowers

and fruits, even if no $S$. polita were present, indicating previous attack. Observations of $S$. polita on $D$.

crumenatum were limited to D. crumenatum's flowering events, with similar damage to D. crumenatum's

flowers as observed on A. graminifolia (Fig. 6). Ovipositing holes in D. crumenatum's fruits were observed as

well.

Distribution Modelling and Mapping:

The average AUC values for each species indicate good model fit (A. graminifolia: AUC $=0.934$, standard deviation $=0.049 ;$ D. crumenatum: $\mathrm{AUC}=0.911$, standard deviation $=0.051 ;$ S. polita $:$ AUC $=0.884$, standard deviation $=0.057)($ Fig. 2). After applying an equal training sensitivity and specificity threshold, there were variations in the average presence threshold for A. graminifolia, D. crumenatum, and S. polita (0.2131, 0.3216 and 0.1797 respectively).

For A. graminifolia, Maxent predicts suitable habitat within the higher elevations of the Cordillera Central, Carite Forest and El Yunque National Forest, which matches our field observations of population occurrence (Fig. 1C).

For D. crumenatum, our models show an affinity towards areas of high land use, with suitable habitat coinciding with urban areas, particularly San Juan and the Caguas-Cayey region, which is where a high density of D. crumenatum populations were observed (Fig. 1B). Dendrobium crumematum appears to prefer lower elevations and largely disturbed habitat, with it's extent noticeably excluding El Yunque National Forest and Cordillera Central. Areas of high land use are not the sole variable necessary for survival. The dry forests on the South side of the island remain unpreferable, even with large urban areas like Ponce. 
bioRxiv preprint doi: https://doi.org/10.1101/828517; this version posted November 2, 2019. The copyright holder for this preprint (which was not certified by peer review) is the author/funder, who has granted bioRxiv a license to display the preprint in perpetuity. It is made available under aCC-BY-NC-ND 4.0 International license.

Foster et al. 12

For S. polita, our models show a negative relationship with land cover. The intact forests of El Yunque and Carite are deemed the most suitable habitat, with hot spots projected in those areas (Fig. 1A). At the same time, urban areas are almost entirely excluded from $S$. polita's extent, particularly San Juan and Caguas, which matches field observations. Additionally, S. polita appears to prefer higher elevations in wet conditions, with their range extending along the Cordillera Central, except for portions with the highest elevations, and into the northern karst region. The scattered pattern across the Northern Karst region are likely a product of the microclimate conditions from the uneven elevation changes of the magotes.

Land cover is one of the most important variables in determining the distribution of all three species (Fig. 3). In each jackknife test, training gain is lowest when land cover is removed from the model, indicating that it contains information found in no other variables (Fig. 3). Land cover also gives D. crumenatum the highest training gain in isolation, providing the most useful information on its own. Interestingly, training gain is higher for D. crumenatum with land cover in isolation than when only land cover is removed from the model. Other than land cover, precipitation and temperature seasonality, along with precipitation during the driest quarter contribute to the model (Fig. 3). This makes sense, considering D. crumenatum's reliance on rainfallinduced temperature drops to trigger their gregarious flowering. For A. graminifolia and S. polita, Max. Temperature in the Warmest Month gives the highest training gain in isolation, with all other temperature layers and elevation providing similar training gains in isolation (Fig. 3). Elevation and temperature are likely closely related, with altitudinal preference possibly a product of their sensitivity to temperature conditions. Correlation tests still have to be run to identify highly correlated variables. Clearly, both species are sensitive to temperature conditions.

Co-occurrence maps reveal how variations and similarities in response to the selected environmental variables influence the degree of inter-species interactions. D. crumenatum heavily favors towards areas of high anthropogenic disturbance, while $S$. polita heavily excludes such environments. This division leads to sparse overlap in their extent, and limited areas of co-occurrence (Fig. 5). In comparison, the similar response of $A$. 
graminifolia and S. polita to environmental variables results in nearly all of A. graminifolia's extent to coincide within S. polita's (Fig. 5).

Response to climate change follows the same species-level patterns observed in variable importance and habitat suitability. Under the most extreme climate change scenario (RCP8.5), our model suggests Puerto Rico will become uninhabitable for both $A$. graminifolia and $S$. polita, with no portions of the island projected as any degree of suitable (Fig. 4). At the same time, our model predicts that such climate conditions will create slightly less suitable conditions for D. crumenatum in Puerto Rico (Fig. 4). Current suitable habitats will become less suitable, while the total area of suitable habitat for D. crumenatum on the island will noticeably decrease (Fig. 4). However, D. crumenatum is still expected to remain on the island, particularly within urban centers. This trend is not particularly strong, since the maximum distribution modelled for D. crumenatum actually shows an increase in habitat suitability and geographic extent. However, the overall trend of decreased suitability remains.

\section{Discussion}

Factors Driving Orchid Distributions and Biotic Interactions:

Accessibility and sensitivity to areas of high anthropogenic disturbance, along with comparisons between determining climatic factors, are what define the distributions of A. graminifolia, D. crumenatum, and their biotic interactions with S. polita.

Land cover is the factor that is most associated with the distribution of $D$. crumenatum across Puerto Rico. The overwhelming prevalence of naturalized $D$. crumenatum within urban areas is a confluence of multiple factors, which allowed for a rapidly spreading D. crumenatum population. First and foremost is the integral role the formal and informal horticultural trade has had on dispersing D. crumenatum to gardens and urban areas across the island. Although it is unknown how D. crumenatum was first introduced to Puerto Rico, a majority of the world's naturalized plants are deliberately introduced, particularly through the horticultural trade (Mack and Erneberg, 2002; Mack, 2003), and the more popular a plant is, the greater the propagule pressure and 
bioRxiv preprint doi: https://doi.org/10.1101/828517; this version posted November 2, 2019. The copyright holder for this preprint (which was not certified by peer review) is the author/funder, who has granted bioRxiv a license to display the preprint in perpetuity. It is made available under aCC-BY-NC-ND 4.0 International license.

Foster et al. 14

the higher the probability of invasional success (Dehnen-Schutz et al., 2007). The rapid spread of Dendrobium

crumenatum across the island over the past decade is certainly connected to its increasing popularity.

Since D. crumenatum is such a recent invasion/naturalization, the evidence of recruitment from initial cultivation is profound. Almost all naturalized populations of $D$. crumenatum appeared to be sourced from a nearby cultivated parent plant. Many orchids were planted in front yards along roadsides, and the role of roads as an effective corridor for exotic seed dispersal has already been identified (Parendes and Jones, 2000;

Mortensen et al, 2009). Rivers are also likely corridors for D. crumenatum spread; however, thus far we are aware of only two populations along riparian habitats.

Furthermore, the current urban extent coincides well with the expected climatic preferences of $D$. crumentatum, as they prefer lower elevations in moist to wet environments, which matches the climatic conditions of urban areas such as San Juan and Caguas (Ewel \& Whitmore 1973; López-Marrero \& Villanueva Colón 2006). The reliance of Dendrobium crumenatum on rain-induced temperature drops to trigger mast flowering creates expected effects on its distribution. Areas with lower amounts of rain at less frequent intervals, such as the dry forests along the southern coast, are uninhabitable for D. crumenatum. Our analyses indicate that temperature and precipitation seasonality likely play a role in their establishment, and response curves indicate that the lower threshold of precipitation during the year also plays a role. Further extrapolation of the response curves still needs to be conducted to determine the specific responses $D$. crumenatum has to these variables.

Land cover provides widespread refugia for D. crumenatum from S. polita attack, adding another complementary aspect in facilitating D. crumenatum establishment within those areas. Exotic increase and native decrease towards urban centers is a widely observed phenomenon (Burton et al. 2005; Almasi, 2000; McKinney, 2002). Our findings reaffirm S. polita absence from the urban matrix (Soifer \& Ackerman, 2019). With a majority of $D$. crumenatum residing almost entirely within areas of high land use, there is little cooccurrence with S. polita and limited biotic interaction (Fig. 5), although that does not exclude the possibility 
that, were it not for land cover, the biotic interaction could noticeably increase. Land cover alone cannot explain species naturalization, particularly for an invasive orchid Such tests will be carried out in the upcoming weeks.

In comparison, no environmental refugia was identified for $A$. graminifolia from $S$. polita attack, with almost all projected presence points falling within S. polita's extent (Fig. 5). There are key differences between A. graminifolia and D. crumenatum that distinguish their ability to take full advantage of possible refugia and characterize their distributions.

Unlike D. crumenatum, A. graminifolia appears highly sensitive to all temperature variables. This sensitivity to high temperatures throughout the year results in establishment only within high elevations, with a minimum benchmark around $500 \mathrm{~m}$. This lower altitudinal limit prevents A. graminifolia from spreading downwards towards the urban extents of San Juan and Caguas. For one A. graminifolia intensively cultivated at lower elevations, we observed significant heat damage on the flowers.

Lack of access to areas of high land use is not the only factor preventing A. graminifolia from escaping weevil attack. Our model suggests that the distribution of $A$. graminifolia is decided by the same environmental variables as $S$. polita, but demonstrates a greater sensitivity to each (Fig. 3). In effect, there should be little to no climate conditions where $A$. graminifolia could survive and $S$. polita could not.

The previously stated role of roads as a corridor for exotic seed dispersal is evident in the spread of $A$. graminifolia across the island. Due to the longer residency on the island, A. graminifolia has infiltrated protected forest reserves far removed from human cultivation, with populations thriving alongside the steep, open-canopied slopes bordering their roads.

Although human dispersal and the proximity to roads likely play a similar role to facilitating the spread of A. graminifolia across the island, highly disturbed areas of land cover might also hinder A. graminifolia establishment within those areas. Since A. graminifolia is a terrestrial orchid, it is likely far more difficult for its seeds to germinate and for successful recruitment to take place within the urban concrete jungle than it is for the 
epiphytic D. crumenatum, which can easily establish on the multiple cultivated trees present in urban areas, pending the presence of the necessary mycorrhizal fungi.

Additionally, unlike D. crumenatum, the orchid resource base within Puerto Rico's mountain towns might be too sparse to support $A$. graminifolia's acquired pollinators, the Centris haemorrhoidalis and Apis mellifera bees, at a population level that would optimize their pollination chances. Pollination surveys of $A$. graminifolia show roughly $11.4 \%$ of $A$. graminifolia flowers might experience a pollinator visit in a rural environment bordering El Yunque (Ackerman et al., unpublished). Indeed, land cover might exacerbate the infrequency of pollination for $A$. graminifolia, which relies on deception rather than rewards, like $D$. crumenatum. This might explain why, despite frequent cultivation as an ornamental within developed areas, most A. graminifolia plants within those environments are without fruits or signs of recruitment, while $D$. crumenatum has ample examples of both. Another possibility is that the terrestrial nature of $A$. graminifolia increases its risk of human intervention after recruitment. While A. graminifolia are frequently used as ornamentals and are often planted in visually-appealing patterns (i.e. a straight line lining a fence or a house), their wind-dispersed seeds rarely abide by these pre-arranged designs. It is possible that A. graminifolia recruits are removed at a much higher rate than $D$. crumenatum recruits, whose gradual spread on surrounding trees is unintrusive to their growers' daily routine or garden upkeep. Surveys with orchid growers would have to be conducted to formally prove that there is a difference in the rate of human intervention of ornamental recruitment between terrestrial and epiphytic plants.

Our projections of $A$. graminifolia largely coincide with the previous models of their distribution on the island, despite the addition of multiple new presence localities between both models (Ackerman, unpublished), further supporting the validity of Maxent to accurately predict species distribution with small sample sizes. Additionally, our models of current distribution agree with those within global $A$. graminifolia models (Kolanowska \& Konowalik, 2014). While Maxent cannot accurately predict distributions in one locality from 
another (Ackerman, unpublished), it can accurately predict habitat suitability in new areas by extracting data

from multiple localities across the entire climatic niche.

Distributions and Interaction Response to Climate Change:

Models of future climate change in Puerto Rico predict an above average temperature gain and decreased trends in precipitation, coinciding with more intense droughts (Khalyani et al. 2015). Further analysis and extrapolation needs to be conducted on the model used from worldclim to determine whether it's predicted conditions match the observed changes and GCMs. Until then, the preliminary assumption is that they remain consistent with those trends.

Within this context, Puerto Rico would be void of all suitable habitat for A. graminifolia and S. polita, and neither species are expected to be present (outside of cultivation) on the island by 2050 in the most extreme climate scenario, while $D$. crumenatum will see only a slight reduction in its extent on the island.

The dramatic response of $A$. graminifolia to drastic climate change is not surprising. It is globally projected that such a climate scenario would reduce the range of suitable habitats within the invasive range of $A$. graminifolia by $88 \%$ by 2080 (Kolanowska \& Konowalik, 2014).

In comparison, the less dramatically reduced extent of $D$. crumenatum represents the diversity in orchid response to climate change that previous studies have observed, with some orchids facing extinction while others proliferate (Kolanowska et al., 2017; Ongaro et al, 2018). So far, orchid response to climate change remains specific to each species, as two orchids with similar climatic preferences can respond to climate change differently (Kolanowska et al., 2017).

With land cover held constant across future projections, the decreased but remaining suitability for $D$. crumenatum within those areas suggests a heavy facilitation for survival by land cover. While it would be expected for a species like D. crumenatum, which prefers the warmer temperatures of lower elevations, to shift or expand its range towards higher elevations in a warming climate, the projected decrease in precipitation 
across the island appears to prevent such a transition. Low precipitation already restricts $D$. crumenatum from suitable temperature conditions on the island, as the dry forests of Puerto Rico remain uninhabitable despite similar temperatures and elevation as San Juan. The remaining presence within urban centers should bring cause for concern, as it would further its prominence within human centers, making it a highly noticeable and common "weed." In order to prevent the spread of D. crumenatum in Puerto Rico, measures must be taken soon to control the population and regulate its dispersal in the horticultural trade. The areas highlighted in this paper can provide a useful map for their management. Management of $A$. graminifolia might not be necessary, or not as urgent as it is for $D$. crumenatum. If anthropogenic-climate change will manage the population in Puerto Rico, any funding or efforts might prove unnecessary.

One of the most important factors in determining a species' response to climate change is not necessarily a climatic variable. Often forgotten in SDM's projecting future distributions are the possible changes in biotic interactions (Tylianakis et al. 2008; Gilman et al. 2010; Davis et al. 1998). For A. graminifolia and D. crumenatum, their future distributions cannot fully be understood without an analysis of their biotic interactions during those times. Although the extent to which $S$. polita attack effects either plant is still being analyzed, its projected absence within a future climate scenario might implicate the extent of D. crumenatum, which is projected to supposedly survive drastic climate change by 2050 . However, the projected extent of $D$. crumenatum within that climate scenario makes weevil absence seemingly inconsequential, as their projected extent within urban environments already excludes weevil presence. It is possible, however, that the more dramatic response of $S$. polita to climate change might provide an RCP scenario where it experiences a reduction in suitable habitat, such as an altitudinal range shift, freeing $D$. crumenatum from any enemy attack and its possible effect of biotic resistance. However, such a scenario could also see D. crumenatum's suitable habitat extending to higher elevations, thereby negating the aforementioned release from enemy attack. Such interactions will be extensively explored as our data is run against the remaining RCP pathways. 
Such freedom from enemy attack due to less drastic climate change seems unlikely for A. graminifolia, since it appears as sensitive, if not more, to projected climate change as S. polita. In this way, no climate scenario should offer A. graminifolia any form of environmental refugia from S. polita. We plan to test this theory over the coming weeks, as we run both species against lower RCP pathways.

These differences between $D$. crumenatum and A. graminifolia in their changing interactions with $S$. polita under climate change can be extrapolated across all orchids in Puerto Rico subject to S. polita attack. Orchids more accustomed to lower elevations and resilient to increasing temperatures could escape $S$. polita attack, while those found at higher elevations and are less resilient to increasing temperatures and/or increased droughts will likely face a similar fate to that of $S$. polita in the wake of impending climate change.

In order to fully understand the distributions of both orchid species in the future, similar population surveys must be conducted on their other biotic interactions. Niche modelling of both orchids' pollinators will shed significant light on how either orchid will truly respond to climate change in the near future, particularly under more conservative RCP pathways. 
bioRxiv preprint doi: https://doi.org/10.1101/828517; this version posted November 2, 2019. The copyright holder for this preprint (which was not certified by peer review) is the author/funder, who has granted bioRxiv a license to display the preprint in perpetuity. It is made available under aCC-BY-NC-ND 4.0 International license.

Foster et al. 20

\section{Graphs:}

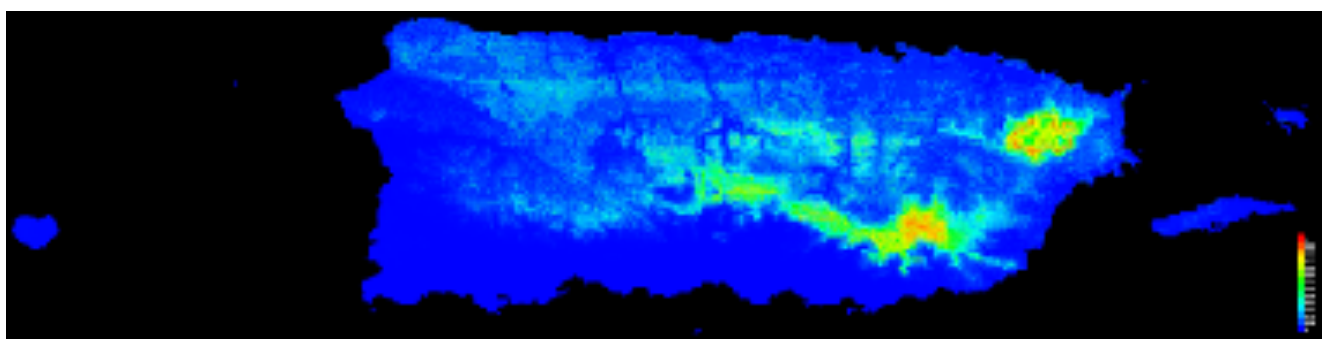

Figure 1A: Average Maxent output of habitat suitability for S. polita under a current climate scenario. Warmer colors indicate areas with better predicted conditions for survival. Most notably, the model suggests preferable conditions in the intact forests of El Yunque National Forest and Carite Forest Preserve, while developed areas are considered unpreferable.

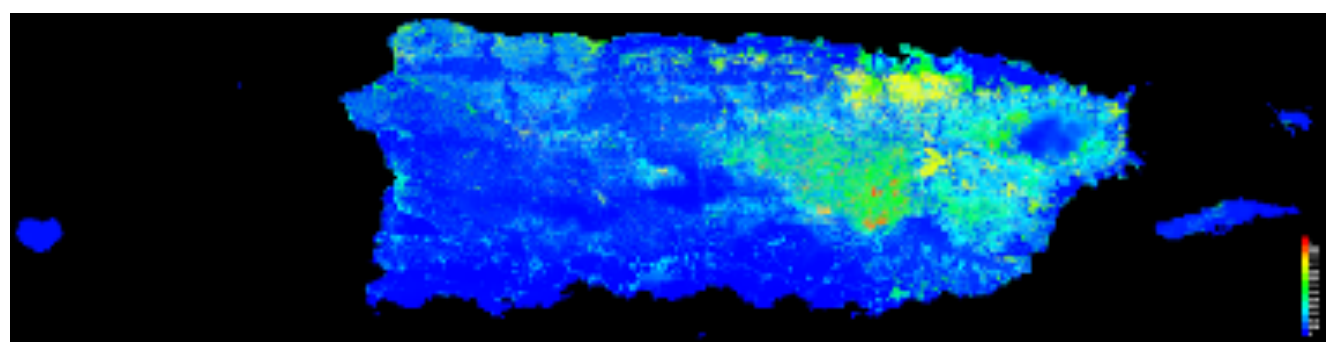

Figure 1B: Average Maxent output of habitat suitability for D. crumenatum under a current climate scenario. Warmer colors indicate areas with better predicted conditions for survival. The model suggests $D$. crumenatum can thrive in areas of high land use, particularly in San Juan and the Caguas-Cayey region. However, urban areas in Puerto Rico's dry forests on the South side of the island remain unpreferable, due to other climatic factors.

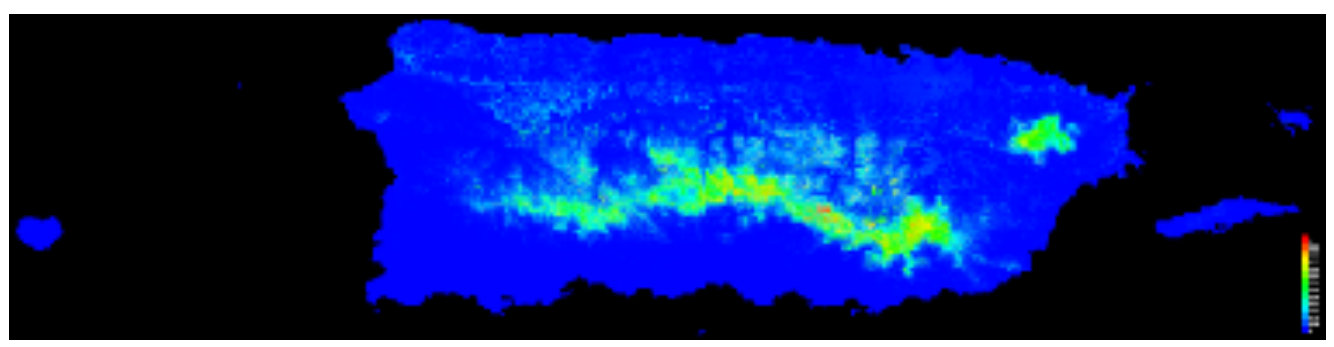

Figure 1C: Average Maxent output of habitat suitability for A. graminifolia under a current climate scenario. Warmer colors indicate areas with better predicted conditions for survival. The model suggests that the high elevations of mountainous regions in the center of the island provide the best conditions for A. graminifolia.

Figure 2: The Area Under the Receiver Operating Characteristic (ROC) curve (AUC) for each species over 10 replicated runs. An AUC $>0.5$ represents a non-random prediction, while AUC $>0.80$ represents a good model and AUC $>0.90$ indicate a very good model. However, these thresholds are arbitrary above random and should be assessed on a per-model basis. A) ROC curve for A. graminifolia; AUC $=0.934$, standard deviation $=0.049$. B) ROC curve for D. crumenatum; $\mathrm{AUC}=0.911$, standard deviation $=0.051 . \mathrm{C}$ ) $\mathrm{ROC}$ curve for $S$. polita; AUC $=0.884$, standard deviation $=0.057$. 
bioRxiv preprint doi: https://doi.org/10.1101/828517; this version posted November 2, 2019. The copyright holder for this preprint (which was not certified by peer review) is the author/funder, who has granted bioRxiv a license to display the preprint in perpetuity. It is made available under aCC-BY-NC-ND 4.0 International license.

Foster et al. 21
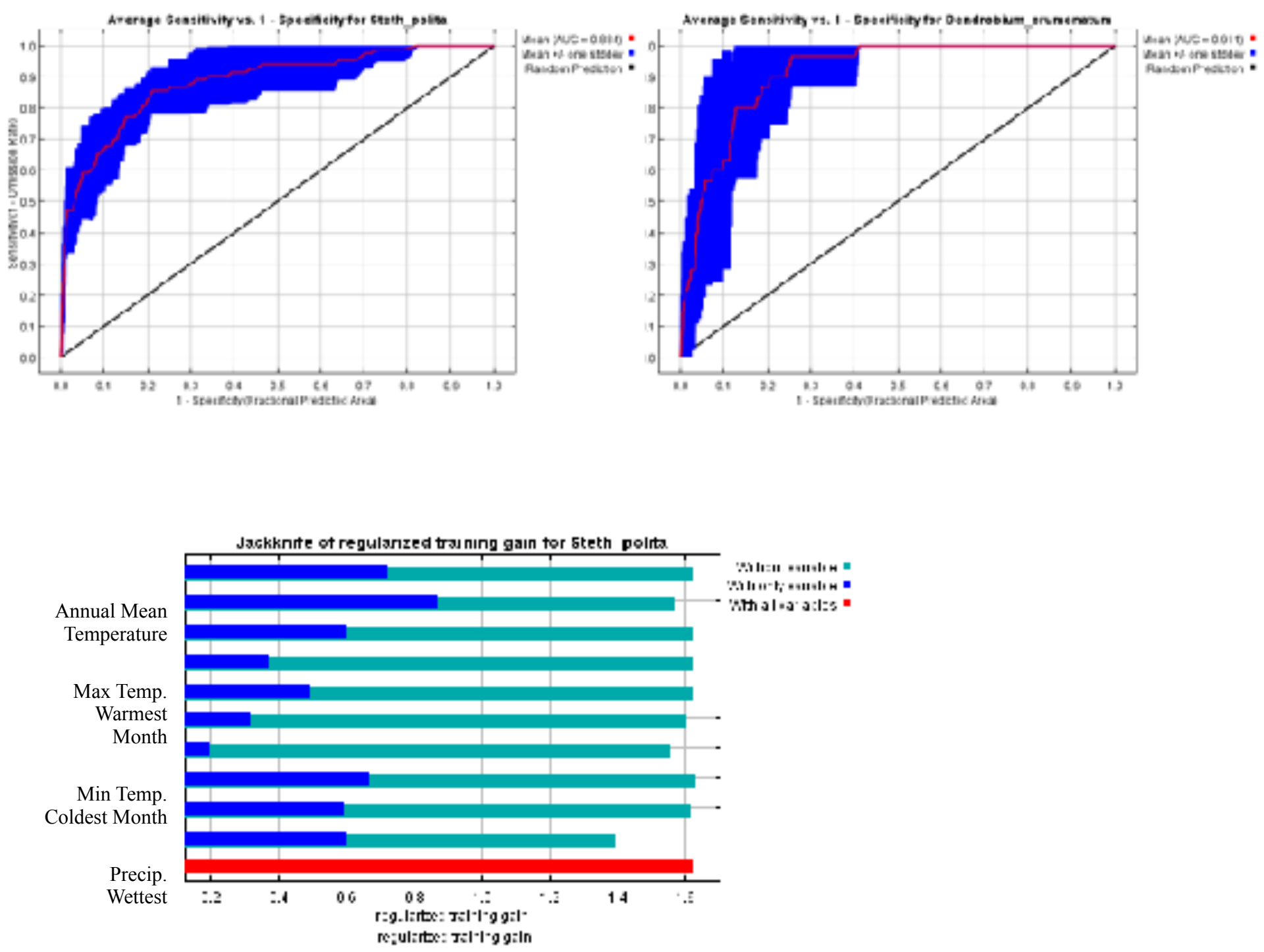

Figure 3: Jacknife tests calculate the regularized training gain when each variable is removed from the model and when only one variable is included in the model. Comparing training gains between variables can identify variable importance. For all three species, training gain is lowest when Land Use is removed from the model, indicating that it contains information found in no other variables. For A. graminifolia and S. polita, Max. Temperature Warmest Month gives the highest training gain in isolation, while Land Use gives D. crumenatum the highest training gain in isolation. These variables provide the most useful information on their own. 
bioRxiv preprint doi: https://doi.org/10.1101/828517; this version posted November 2, 2019. The copyright holder for this preprint (which was not certified by peer review) is the author/funder, who has granted bioRxiv a license to display the preprint in perpetuity. It is made available under aCC-BY-NC-ND 4.0 International license.

Foster et al. 22
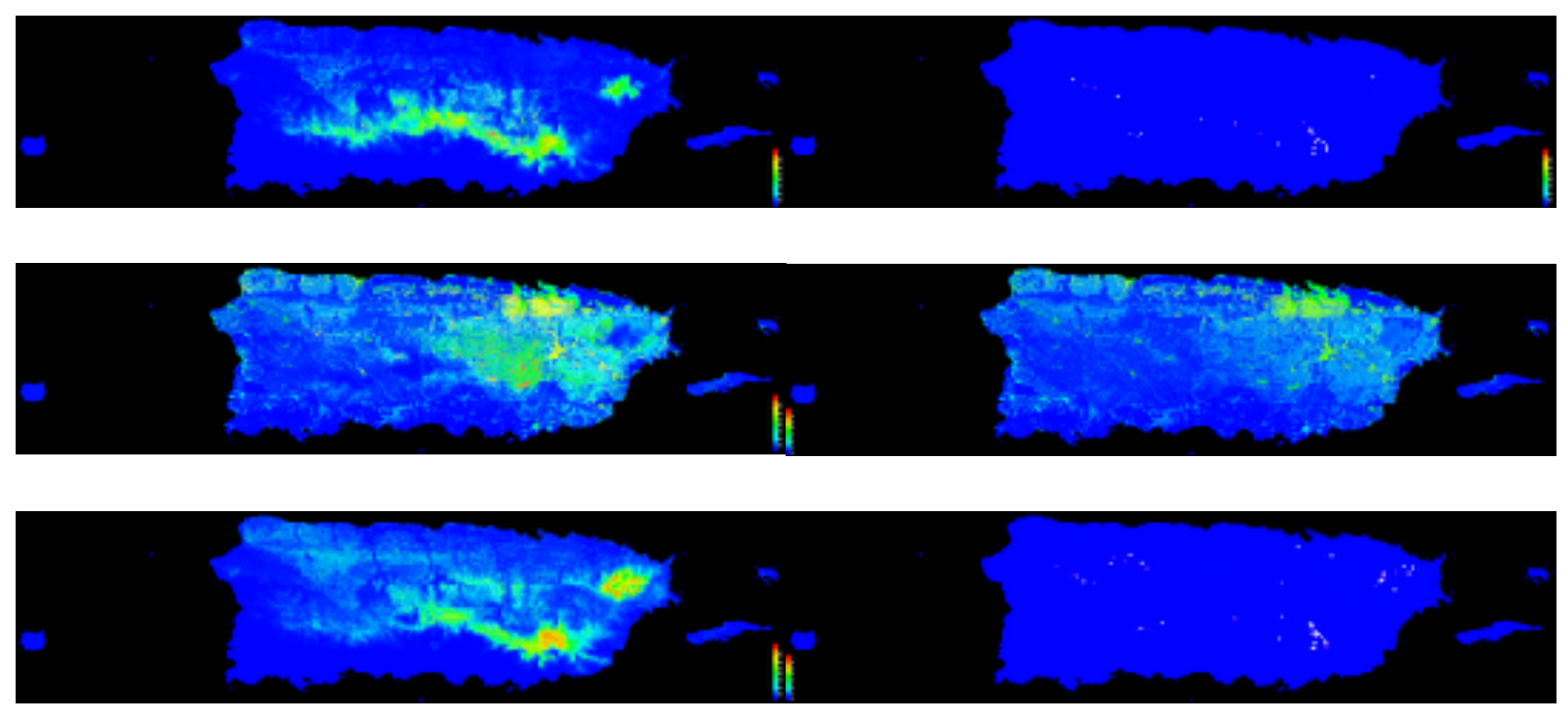

Figure 4: Compares the average Maxent output of habitat suitability for each species in the current climate (left) against the habitat suitability in 2050 with the most extreme climate scenario (RCP8.5) (right). Warmer colors indicate areas with better predicted conditions for survival. 
bioRxiv preprint doi: https://doi.org/10.1101/828517; this version posted November 2, 2019. The copyright holder for this preprint (which was not certified by peer review) is the author/funder, who has granted bioRxiv a license to display the preprint in perpetuity. It is made available under aCC-BY-NC-ND 4.0 International license.

Foster et al. 23

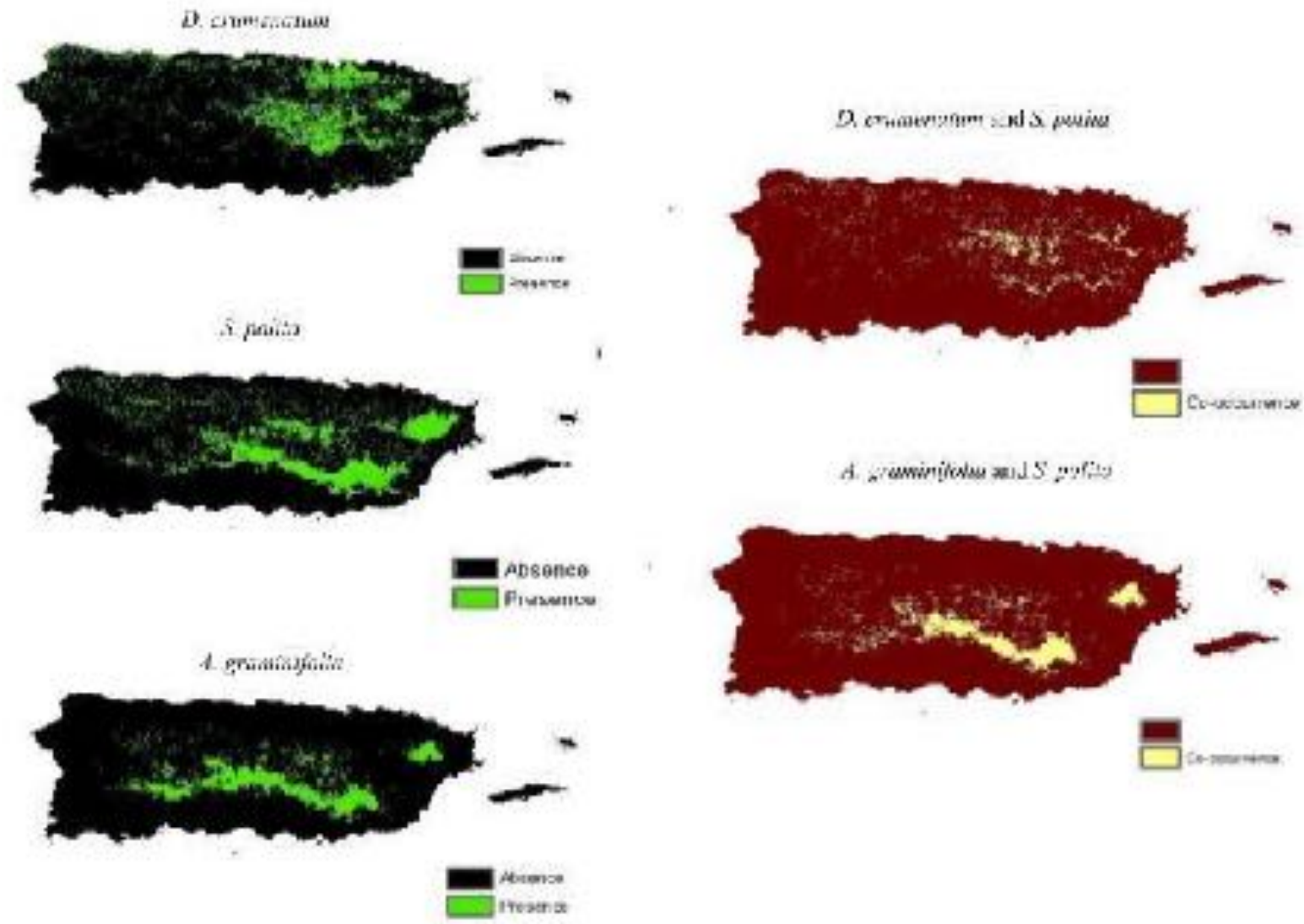

Figure 5: Maps on the left show the distribution of all three species after an Equal training specificity and sensitivity threshold was applied. Green represents presence, while black shows absence. Threshold values for A. graminifolia $=0.21$; D. crumenatum $=0.32$; $\mathrm{S}$. polita $=0.18$. Maps on the right combine the presence-absence maps of each orchid to S. polita's. Yellow areas indicate regions where both species co-occur.

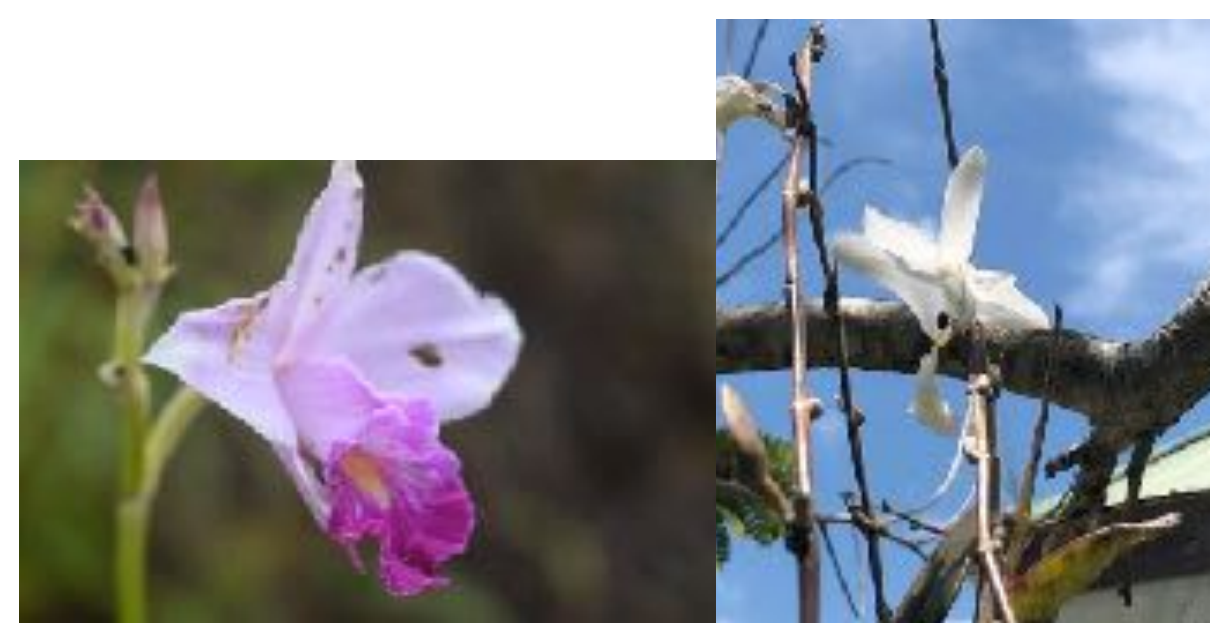

Figure 6: Photos taken by authors of $A$. graminifolia and $D$. crumenatum with petal damage from S. polita attack and a resident $S$. polita. 


\section{References}

Ackerman, J. D. (1995) An orchid flora of Puerto Rico and the Virgin Islands. Memoirs of the New York Botanical Garden, 73, 1-203.

Ackerman, J. D. (2007) Invasive orchids: weeds we hate to love? Lankesteriana, 7, 19-21.

Ackerman J. D. (2012) Orchids gone wild: discovering naturalized orchids in Hawaii. Orchids, 81: 88-93.

Almasi, K. N. (2000). A non-native perennial invades a native forest. Biological Invasions, 2, 219-230.

Araújo, M. B., \& Peterson, A. T. (2012). Uses and misuses of bioclimatic envelope modeling. Ecology, 93, 1527-1539.

Axelrod F. A. (2011) A systematic vademecum to the vascular plants of Puerto Rico. BRIT Press, Fort Worth, Texas.

Barredo, J. I., Strona, G., de Rigo, D., Caudullo, G., Stancanelli, G., \& San-Miguel-Ayanz, J. (2015). Assessing the potential distribution of insect pests: case studies on large pine weevil (H ylobius abietis L) and horse-chestnut leaf miner (C ameraria ohridella) under present and future climate conditions in E uropean forests. EPPO Bulletin, 45(2), 273-281.

Brooks, C. J., \& Hewitt, J. (1910). Notes on the Fertilisation of a Few Orchids in Sarawak. Journal of the Straits Branch of the Royal Asiatic Society, (54), 99-106.

Burton ML, Samuelson LJ, Pan S (2005) Riparian woody plant diversity and forest structure along an urban-rural gradient. Urban Ecosyst 8(1):93-106. https://doi.org/10.1007/s11252-005-1421-6

Coops, N. C., \& Waring, R. H. (2011). Estimating the vulnerability of fifteen tree species under changing climate in Northwest North America. Ecological Modelling, 222(13), 2119-2129.

D'Antonio, C. M., and T. L. Dudley. 1995. Biological invasions as agents of change on islands versus mainlands. In P. M. Vitousek, L. L. Loope, and H. Adsersen (Eds.). Islands: Biological diversity and ecosystem function, pp. $103-121$. Springer, Stanford, California .

Daehler CC 1998 Taxonomic distribution of invasive angiosperm plants: ecological insights and comparison to agricultural weeds. Biological Conservation 84:167-180.

Davis, A. J., Jenkinson, L. S., Lawton, J. H., Shorrocks, B., \& Wood, S. (1998). Making mistakes when predicting shifts in species range in response to global warming. Nature, 391(6669), 783.

D. crumenatum Botanical Records. (n.d.). Retrieved June 12, 2019, from http://herbario.uprrp.edu/bol/uprrp/search? genus $=$ dendrobium $\& s p 1=$ crumenatum $\&$ exactmatch=true $\& v i e w=$ specimens 
Dehnen-Schmutz, K., Touza, J., Perrings, C., \& Williamson, M. (2007). A century of the ornamental plant trade and its impact on invasion success. Diversity and Distributions, 13, 527-534.

Denslow, J. S., Space, J. C., \& Thomas, P. A. (2009). Invasive exotic plants in the tropical Pacific islands: patterns of diversity. Biotropica, 41, 162-170.

Elith, J., Kearney, M., \& Phillips, S. (2010). The art of modelling range-shifting species. Methods in Ecology and Evolution, 1, 330-342.

Ewel, J. J., Whitmore, J. L. (1973). The ecological life zones of Puerto Rico and the US Virgin Islands. Research Paper No. ITF-18. Río Piedras: USDA Forest Service Institute of Tropical Forestry.

Falcón, W., Tremblay, R. L. (2018) From the cage to the wild: introductions of Psittaciformes to Puerto Rico. PeerJ 6::e5669; DOI 10.7717/peerj.5669

Fick, S. E., \& Hijmans, R. J. (2017). Worldclim 2: New 1-km spatial resolution climate surfaces for global land areas. International Journal of Climatology.

Gilman, S. E., Urban, M. C., Tewksbury, J., Gilchrist, G. W., \& Holt, R. D. (2010). A framework for community interactions under climate change. Trends in Ecology \& Evolution, 25, 325-331.

Goh C.J. Strauss M.S. Arditti J. 1982 Flower induction and physiology in orchids. Pages 213-241 in Arditti J. (ed.), Orchid biology: Reviews and perspectives II. Cornell University Press, Ithaca, NY

Gould WA, Alarcon C, Fevold B, Jimenez ME, Martinuzzi S, Potts G, Quinones M, Mariano S, Ventosa E (2008) The Puerto Rico gap analysis project volume 1: Land cover, vertebrate species, distributions, and land stewardship. USDA Forest Service International Institute of Tropical Forestry.

Holway, D. A. (1995). Distribution of the Argentine ant (Linepithema humile) in northern California. Conservation Biology, 9, 1634-1637.

Kolanowska, M., \& Konowalik, K. (2014). Niche conservatism and future changes in the potential area coverage of Arundina graminifolia, an invasive orchid species from Southeast Asia. Biotropica, 46, 157-165.

Kolanowska, M., \& Rykaczewski, M. (2017). From the past to the future-glacial refugia, current distribution patterns and future potential range changes of Diodonopsis (Orchidaceae) representatives. Lankesteriana, 17, 315-327.

Kolanowska, M., Kras, M., Lipińska, M., Mystkowska, K., Szlachetko, D. L., \& Naczk, A. M. (2017). Global warming not so harmful for all plants; response of holomycotrophic orchid species for the future climate change. Scientific Reports, 7, 12704.

Lenoir, J., Gégout, J. C., Marquet, P. A., De Ruffray, P., \& Brisse, H. (2008). A significant upward shift in plant species optimum elevation during the 20th century. Science, 320, 1768-1771. 
Lockwood, J. L., Hoopes, M. F., \& Marchetti, M. P. (2007). Invasion Ecology. Blackwell Publishing, Malden, MA.

López- Marrero, T. M., Villanueva Colón, N. (2006) Atlas ambiental de Puerto Rico. Editorial de la Universidad de Puerto Rico, San Juan.

Mack, R.N. (2003) Global plant dispersal, naturalization, and invasion: pathways, modes, and circumstances. Invasive species: vectors and management strategies (ed. by G.M. Ruiz and J.T. Carlton), pp. 3-30. Island Press, Washington.

Mack, R., \& Erneberg, M. (2002). The United States Naturalized Flora: Largely the Product of Deliberate Introductions. Annals of the Missouri Botanical Garden, 89, 176-189. doi:10.2307/3298562

Martorell, L. F., \& Gaud, S. M. (1974). Orchid pests in Puerto Rico. The Journal of Agriculture of the University of Puerto Rico, 58, 105-124.

McCarthy, M. P., Best, M. J., \& Betts, R. A. (2010). Climate change in cities due to global warming and urban effects. Geophysical Research Letters, 37(9).

McKinney, M. L. (2002). Urbanization, Biodiversity, and Conservation The impacts of urbanization on native species are poorly studied, but educating a highly urbanized human population about these impacts can greatly improve species conservation in all ecosystems. Bioscience, 52, 883-890.

McKinney ML (2006) Urbanization as a major cause of biotic homogenization. Biol Conserv 127(3):247-260. https:// doi.org/10.1016/j.biocon.2005.09.005

Mortensen, D. A., Rauschert, E. S., Nord, A. N., \& Jones, B. P. (2009). Forest roads facilitate the spread of invasive plants. Invasive Plant Science and Management, 2(3), 191-199.

O’Dowd, D. J., Green, P. T., \& Lake, P. S. (2003) Invasional 'meltdown' on an oceanic island. Ecology Letters, 6, 812-817.

Oke, T. R. (1973). City size and the urban heat island. Atmospheric Environment (1967), 7(8), 769-779.

Ongaro, S., Martellos, S., Bacaro, G., De Agostini, A., Cogoni, A., \& Cortis, P. (2018). Distributional pattern of Sardinian orchids under a climate change scenario. Community Ecology, 19(3), 223-232.

Parendes, L. A., \& Jones, J. A. (2000). Role of light availability and dispersal in exotic plant invasion along roads and streams in the HJ Andrews Experimental Forest, Oregon. Conservation Biology, 14(1), 64-75.

Parker, D. E. (2010). Urban heat island effects on estimates of observed climate change. Wiley Interdisciplinary Reviews: Climate Change, 1(1), 123-133.

Phillips SJ, Dudik M, Schapire RE (2018) Maxent software for modeling species niches and distributions (Version 3.4.1). Available from url: http://biodiversityinformatics.amnh.org/open_source/maxent/. Accessed 22 July 2019 
Puerto Rico GAP Analysis Project. (2006). PRGAP Landcover. USDA Forest Service, International Institute of Tropical Forestry.

Pulwarty, R. S., Nurse, L. A., \& Trotz, U. O. (2010). Caribbean islands in a changing climate. Environment, 52(6), 16-27.

Recart, W., Ackerman, J. D., \& Cuevas, A. A. (2013). There goes the neighborhood: apparent competition between invasive and native orchids mediated by a specialist florivorous weevil. Biological Invasions, 15(2), 283-293.

Rojas-Sandoval, J., Acevedo-Rodríguez, P. (2015) Naturalization and invasion of alien plants in Puerto Rico and the Virgin Islands. Biological Invasions, 17, 149-163.

Seifriz, W. (1923). The gregarious flowering of the orchid Dendrobium crumenatum. American Journal of Botany, 10(1), 32-37.

Sin H, Beard KH, Pitt WC 2008. An invasive frog, Eleutherodactylus coqui, increases new leaf production and leaf litter decomposition rates through nutrient cycling in Hawaii. Biological Invasions 10::335-345.

Soifer, L. G., \& Ackerman, J. D. (2019). Extremes of forest-urban gradient offer some refuge for alien orchid invasion. Biological Invasions, 21(6), 2143-2157.

Tylianakis, J. M., Didham, R. K., Bascompte, J., \& Wardle, D. A. (2008). Global change and species interactions in terrestrial ecosystems. Ecology letters, 11(12), 1351-1363.

University of Puerto Rico, \& Department of Plant Sciences. (n.d.). A. Graminifolia Collections, Herbario UPRRP. Retrieved June 10, 2019, from http://herbario.uprrp.edu/Bol/uprrp/Results

Vila, M., \& Pujadas, J. (2001). Land-use and socio-economic correlates of plant invasions in European and North African countries. Biological conservation, 100(3), 397-401.

Vitousek, P. M., Walker, L. R. (1989) Biological invasion by Myrica faya in Hawai'i: plant demography, nitrogen fixation, ecosystem effects. Ecological Monographs 59, 247-265.

Walther, G. R., Post, E., Convey, P., Menzel, A., Parmesan, C., Beebee, T. J., ... \& Bairlein, F. (2002). Ecological responses to recent climate change. Nature, 416(6879), 389. 